\title{
Studies on Morphological and Phytochemical Variation between Two Varieties of Fenugreek (Trigonella foenum-graecum L.) at Different Concentration of Sodium Azide
}

\author{
Akash T. Ingle*, Amol D. Sable and Rahul K. Zote \\ Department of Plant Biotechnology SDMVM's College of Agricultural Biotechnology, Georai \\ Tanda, Paithan Road, Aurangabad (M.S.) - 431001, India \\ *Corresponding author
}

\begin{abstract}
A B S T R A C T
Keywords

Morphological,

Phytochemical,

Fenugreek, Sodium azide

Article Info

Accepted:

12 September 2018

Available Online:

10 October 2018

The present investigation entitled "Studies on morphological and phytochemical variation between two varieties of fenugreek (Trigonella foenum-graecum L.) at different concentration of sodium azide" was conducted in Department of Plant Biotechnology in SDMVM's college of Agriculture Biotechnology, Georai Tanda, Aurangabad. The aim of study was to see the effect of sodium azide on germination percentage and to study the morphological and phytochemical variation between of two varieties of fenugreek (Gaytri and Haldighati). It was observed that the increasing doses of sodium azide have showed adverse effect on germination (\%), survivability (\%) and number of leaves in both of the variety (gaytri and Haldighati). The highest plant height was recorded $(8.80 \mathrm{~cm})$ at the treatment T2 $(3.00 \mathrm{mM})$. The highest number of pod (7.46) observed at both of the varieties (gaytri and haldighati) at the treatment T3 $(4.5 \mathrm{mM})$. Similar result observed by rajani prabha et al., (2010). In the phytochemical analysis showed that the absence of flavonoids and the starch are not determined in the presence study.
\end{abstract}

\section{Introduction}

Fenugreek (Trigonella foenum-graecum L.) is one of the oldest crops of the world and grown for its medicinal values. It is a self-pollinated diploid species with chromosome number of $2 \mathrm{n}=16$ (Frayer, 1930). The fenugreek, also known as "Methi", is an important leafy vegetable cum seed spices belongs to the family Fabaceae. Fenugreek is mainly cultivated in India, Argentina, Egypt, Morocco, Southern France, Algeria, Ethiopia and Lebanon (Bose et al., 1993). In India it is mainly cultivated in Rajasthan, Gujarat, Tamil
Nadu, Andhra Pradesh, Uttar Pradesh, Himachal Pradesh and Haryana with total area of 247000 hectares with production of 219000 metric tonnes (Anonymous, 2015-16a). Plant extracts are known for their ethno medical traditions, that is they possess various pharmaceutical and nutraceutical properties. Fenugreek is one such plant that possesses phytoconstituents such as flavonoids, alkaloids, terpenoids, steroids, saponins, anthocyanin and tannins (Sumayya et al., 2012). With the emergence of multiple antibiotic resistant strains of microorganisms, great interest has been shown in the search of 
potential plant compounds for therapeutic, medicinal, aromatic and aesthetic uses (Gurinder and Daljit, 2009; Newman and Cragg, 2007). Phytochemicals are natural and non-nutritive bioactive compounds produced by plants, which act as protective agents against external stress and pathogenic attack. It could beused as single therapeutic agents or as combined formulations in drug development (Rashmi et al., 2011).

Physical and chemical mutagens induce physiological damages (injury), gene mutations (point mutations) and chromosomal aberrations in the biological material in M1 generation (Gaul, 1970). Gamma rays, an energetic form of electromagnetic radiations are known to be the most popular mutagens for their simple application, good penetration, reproducibility, high mutation frequency and less disposal problems (Chahal and Ghosal, 2002). Ethyl methane sulphonate (EMS), a chemical mutagen of the alkylating group has been reported to be the most effective and powerful mutagen and usually causes high frequency of gene mutations and low frequency of chromosome aberrations in plants (Van Harten, 1998; Khatri et al., 2005). Sodium azide $\left(\mathrm{NaN}_{3}\right)$ is the least dangerous and the most efficient mutagen and has been reported to be mutagenic in several crop species (Adamu and Aliyu, 2007; Mostafa, 2011). The mutagenicity of sodium azide is arbitrated through the formation of an organic metabolite which enters the nucleus, interacts with DNA and generates point mutations in the genome. According to Nilan et al., (1977), SA is relatively safe to handle, inexpensive and noncarcinogenic as compared to other mutagens. In mutation breeding studies, it is important to determine a suitable dose/concentration of mutagen for a crop plant which can be employed for inducing maximum variability through point mutations. Seed germination, seedling growth, pollen sterility and chromosomal aberration are the commonly used criteria for studying radiosensitivity in plants (Kon et al., 2007; Lal et al., 2009; Sangle et al., 2011; Sheikh et al., 2012). The aim of present study was to determine the response of fenugreek seeds to gamma rays, EMS and sodium azide based on germination and survival percentage, rootshoot length, and pollen fertility with the main aim of identifying appropriate dose/conc. of these mutagens for induction of desirable mutations.

Present study involves two genotypes 'Gaytri and Haldighati' from a local seed market as base plant population utilized to evaluate mutagenic effects of sodium azide induction on two different varieties of fenugreek and characterize the desirable traits induced after mutation. Two different objectives of the present investigation are, 1. To study the germination percentage of different varieties of fenugreek at different concentration of sodium azide. 2 . To study the morphological and phytochemical variation between different varieties of fenugreek at different concentration of sodium azide.

\section{Materials and Methods}

The present investigation entitled, "Effects of sodium azide induction on two different varieties of fenugreek (Trigonella foenumgraecum L.)" was conducted in Department of Plant Biotechnology in SDMVM's college of Agriculture Biotechnology, Georai Tanda, Aurangabad. The aim of study is to see the effect of sodium azide induction of two varieties of fenugreek. The detailed information on the experimental technique adopted during the study period was presented in this chapter.

\section{Experimental details}

To study the performance of sodium azide in mutation induction on 2 different varieties of 
fenugreek as the detailed below, the experiment was laid out in RBD with 3 replication other detailed of field experiment are given in table 1 .

\section{Treatment details}

Treatment details of different concentration of sodium azide (SA) given two different varieties of fenugreek (Gaytri and Haldighati) The details of the treatment are given in table 2.

\section{Methodology}

Healthy and dry seeds of the varieties Gaytri and Haldighati of fenugreek was selected which are having uniform size. The seeds presoaked 14 hours in distilled water were treated with the different concentration of Sodium azide used for chemical mutagenic treatments were $(00 \mathrm{mM}, \quad 1.5 \mathrm{mM}$, 3.0mM,4.5mM $\quad 6.0 \mathrm{mM} \quad 7.5 \mathrm{mM}, 9.0 \mathrm{mM}) \quad 4$ hours at room temperature and three replicates of each treatment were maintained for reproducibility. The sodium azide (merck) solution was prepared in $0.1 \mathrm{M}$ phosphate buffer at $\mathrm{pH} 3$. After treatment, the seeds were thoroughly washed overnight under running tap water to remove the residual mutagen sticking to the seed coat. A set of 50 seeds in three replicates was kept in distilled water to serve as control. (Prabha et al., 2010).

\section{Plant growth characters}

Three pot of each replication from each pot were selected for recording biometric observations. The biometric observations viz., Survivability percentage, number of leaves, number of pod, height of plant, number of pod

\section{Survivability percentage}

The survivability percentage was measured after 30 DAS.

\section{Number of leaves per plant}

The number of leaves proliferated was measure, after 60 DAS.

\section{Average height of the plant}

The plant length was measured in $(\mathrm{cm})$ after 60 DAS.

\section{Number of pod per plant}

The number of pod was counted after 90 DAS.

\section{Preparation of extract}

The extraction and phytochemical analysis was performed according to Anbumalarmathi et al., (2016) with slight modification. Leaves of Trigonella foenum-graecum L. were thoroughly washed thrice in sterile distilled water, shade dried and ground separately to a fine powder using a mortal pestle. The extract was prepared using ethanol and methanol. After that the extract was filtered using Whatman no. 1 filter paper.

\section{Phytochemical analysis}

Phytochemical analysis obtained from the leaves and shoot tip extracts were analysed as follows:

Test for flavonoids (Treaseand Evans, 1989)

$2 \mathrm{ml}$ of the plant extract, $1 \mathrm{ml}$ of $2 \mathrm{~N}$ sodium hydroxide solution was added. The resulting yellow solution indicated the presence of flavonoids.

\section{Test for starch (Khandelwal, 2005)}

A small amount of the powdered plant part (seed), a few millilitre of concentrated sulphuric acid was added. A prominent colour change to black indicated the presence of starch. 


\section{Results and Discussion}

Fenugreek (Trigonella foenumgraecum L.), is annual, self-pollinated legume plant belonging to the family Fabacecae and commonly called methi. Mutation induction has been accepted as a useful tool in plant breeding programs to provide maximum variability. Present topic emphasis is to study the effect sodium azide induction on two different varieties of fenugreek cultivar Gaytri and Haldighati. After treatment with single mutagen at various concentration seeds were sown and different observations were recorded at harvesting.

Effect of SA on number of leaves of fenugreek

In the present investigation, the maximum number of leaves (26.33) recorded in the treatment $(0.0 \mathrm{mM}$ of sodium azide $)$ in the both of the variety, gaytri and haldighati. In the treatment T6 $(9.0 \mathrm{Mm}$ of sodium azide) showing minimum number of leaves (15.00) in the variety gaytri and (13.66) in the variety galdighati (Table 3).

\section{Effect of SA on plant height of fenugreek}

In the present study, the highest plant height was recorded at $(8.80 \mathrm{~cm})$ in both of the variety gaytri and haldighati at the treatment T2 (3.0 mM of sodium azide). The treatment T0 (0.0mM of soudium azide) showing plant height $(8.00 \mathrm{~cm})$ in the variety gaytri and $(8.06 \mathrm{~cm})$ plant height in the variety of haldighti. The treatment T6 $(9.0 \mathrm{Mm})$ showing minimum number of plant height $(4.16 \mathrm{~cm})$ in the variety gaytri and $(4.26 \mathrm{~cm})$ in the variety haldighati (Fig. 1).

Table.1 Experimental details

\begin{tabular}{|ll|}
\hline 1. & Crop \\
\hline 2. & Varieties \\
\hline 3. & Season \\
\hline 4. & Sowing time \\
\hline 5. & Statistical design \\
\hline 6. & No. of treatment \\
\hline 7. & No. of replication \\
\hline 8. & Location \\
\hline & \\
\hline
\end{tabular}

Fenugreek (Trigonella foenumgraecum L.)

Gaytri and Haldighati

Annual Crop

January- March

RBD (Randomized Block Design)

7

3

SDMVM's College Of Agril Biotechnology

Table. 2 Treatment details

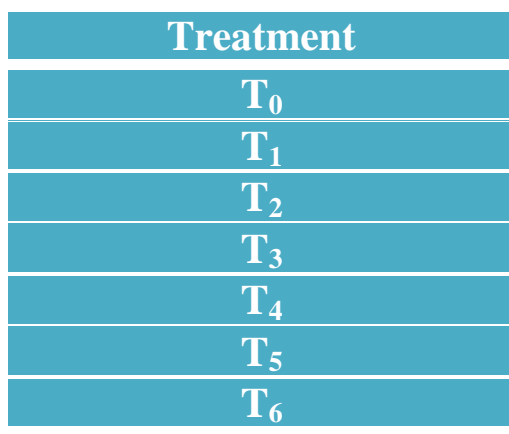

Sodium azide (mM)

\begin{tabular}{|c|}
\hline Control \\
\hline $1.5(\mathrm{mM})$ \\
\hline $3.0(\mathrm{mM})$ \\
\hline $4.5(\mathrm{mM})$ \\
\hline $6.0(\mathrm{mM})$ \\
\hline $7.5(\mathrm{mM})$ \\
\hline $9.0(\mathrm{mM})$ \\
\hline
\end{tabular}


Table.3 Effect of SA application on number of leaves of different varieties of fenugreek

\begin{tabular}{|c|c|c|}
\hline Treatments & Gaytri & Haldighati \\
\hline $\mathrm{T}_{0}(0.0 \mathrm{mM})$ & 26.36 & 26.36 \\
\hline $\mathrm{T}_{1}(1.5 \mathrm{mM})$ & 21.33 & 19.66 \\
\hline $\mathrm{T}_{2}(3.0 \mathrm{mM})$ & 20.66 & 20.00 \\
\hline $\mathrm{T}_{3}(4.5 \mathrm{mM})$ & 19.00 & 19.00 \\
\hline $\mathrm{T}_{4}(6.0 \mathrm{mM})$ & 18.00 & 16.66 \\
\hline $\mathrm{T}_{5}(7.5 \mathrm{mM})$ & 16.33 & 14.00 \\
\hline $\left.\mathrm{T}_{6} 9.0 \mathrm{mM}\right)$ & 15.00 & 13.66 \\
\hline $\mathrm{SE} \pm$ & 2.19 & 1.98 \\
\hline $\mathrm{CD}$ & 2.63 & 2.50 \\
\hline
\end{tabular}

Table.4 Effect of SA application on phytochemical analysis of two different varieties of fenugreek

\begin{tabular}{|c|c|c|}
\hline Phytochemical constituents & Leaf extract (methanol) & Leaf extract (ethanol) \\
\hline Flavonoids & - & - \\
\hline Starch & N.D & N.D \\
\hline
\end{tabular}

' + ' = positive, ' $` ‘=$ negative, 'N.D'= Not determined.

Fig.1 Effect of SA application on plant height of different varieties of fenugreek

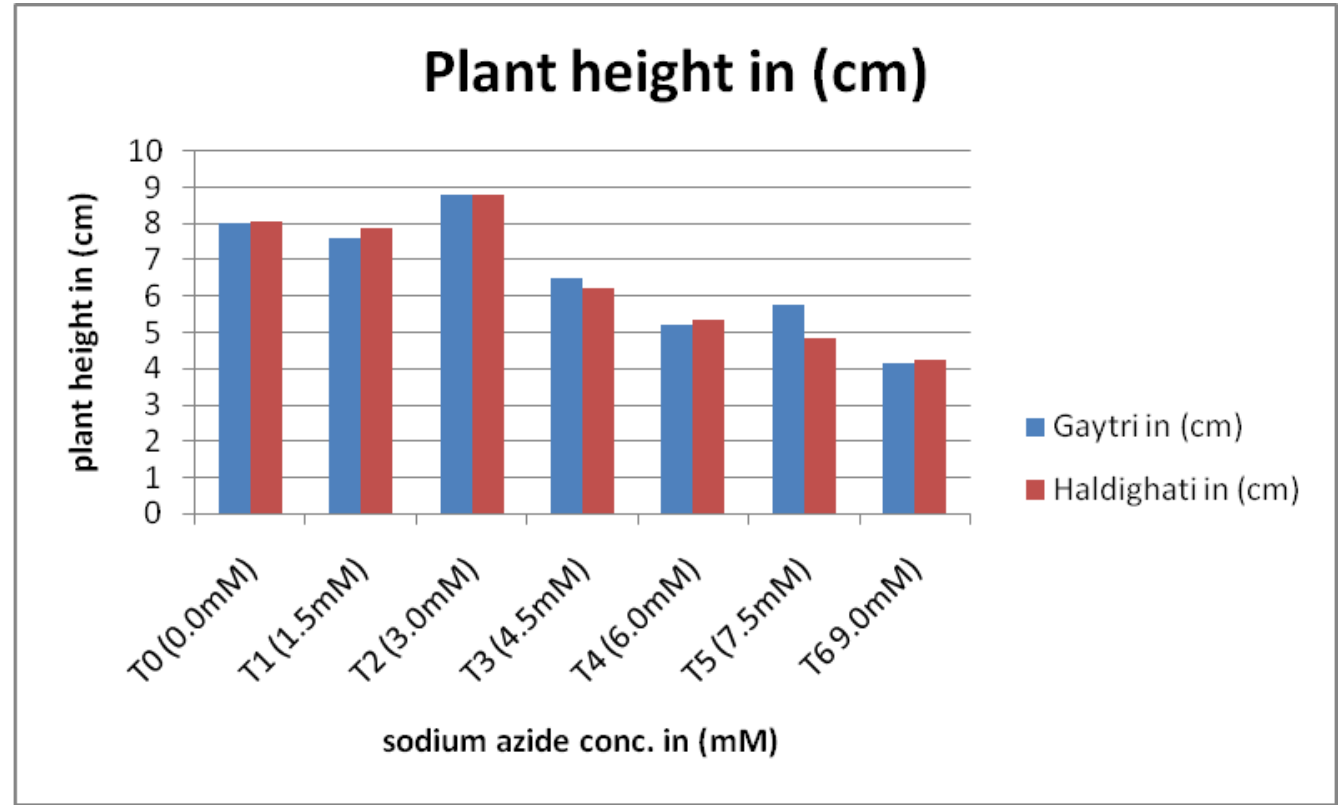


Fig.2 Effect of sodium azide on phytochemical analysis of fenugreek (Gaytri and Haldighati)

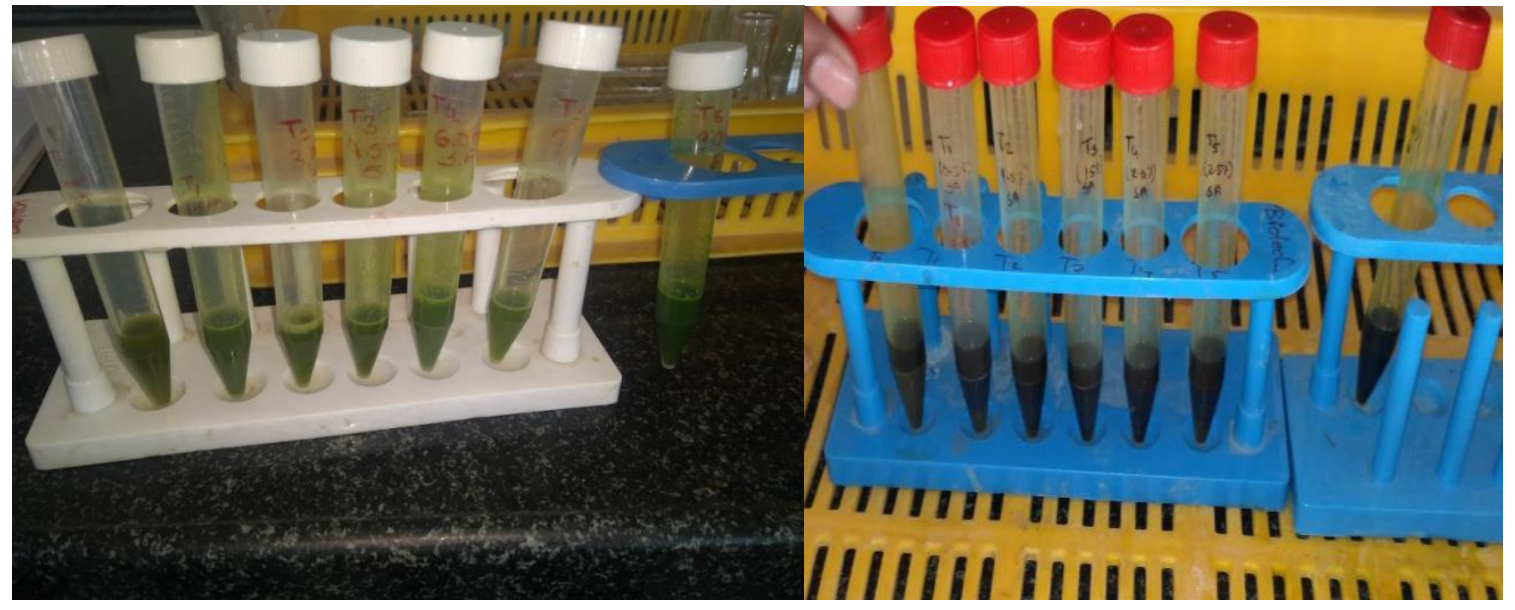

Effect of SA on number of pod of fenugreek

In the present investigation, highest number of pod (7.46) recorded in the treatment $\mathrm{T} 4$ (6.0Mm of sodium azide) in both of the variety, gaytri as well as haldighati. The treatment T0 (control) showing number of pod (7.33) in the variety of gaytri and (7.00) in the variety of haldighati. And the lowest number of pod recorded at the treatment T6 ( $9.0 \mathrm{mM}$ of sodium azide) in both of variety (2.86).

\section{Phytochemical analysis}

In the phytochemical analysis showed that the absence of flavonoids and the starch are not determined in the presence study. Similar result recorded by Anbumalarmathi et al., (2016) (Fig. 2 and Table 4).

It was observed that the increasing doses of sodium azide was showed adverse effect on germination percentage (\%), survivability percentage (\%) and number of leaves in both of the variety (gaytri and Haldighati). The highest plant height was recorded $(8.80 \mathrm{~cm})$ at the treatment $\mathrm{T} 2(3.00 \mathrm{mM})$. The highest number of pod (7.46) observed at both of the varieties (gaytri and haldighati) at the treatment T3 (4.5mM). Similar result observed by Rajani Prabha et al., (2010). In the phytochemical analysis showed that the absence of flavonoids and the starch are not determined in the presence study. Similar result recorded by Anbumalarmathi et al, (2016).

\section{References}

Anbumalarmati. J. Aruna S.S. and Esther S.2016. Fenugreek (Trigolella foenum graecum L.): Antibacterial activity of its phytochemical constituents. Int. J. Ayur. Herb. Med., 6:2 2166-217

Anonymous, 2015-16 Indian Horticulture Database. National Horticulture Board, Ministry of Agriculture, Gurgaon.

Anonymous, 2015-16 Directorate of Horticulture, Government of Rajasthan. www.horticulture.rajasthan.gov.in

Bose, T.K., Som, M.G. and Kabil, J. 1993. Vegetables Crops. Naya Prakash, Kolkata (WB). Pp. 559.

Chahal G. S. And Gosal S.S. 2002. Principles and Procedures of Plant Breeding. Oxford: Alpha Science International Ltd. Pp.399-412.

Farooqi, A.A. Sreeramu, B.S. And Srinivasappa, K.N. 2003. Tropical spice crops and their cultivation. Kavyakala 
Prakashana, Bengaluru.

Frayer, J.R. 1930. Chromosome Atlas of flowering plants. George Allen and Urwin, London, Pp. 519.

Peteropoulos, G.A. 2002. Fenugreek, The genus Trigonella. First edition by Taylor and Francis, London and New York, pp. 1-27.

Rajani Prabha, Vineeta Dixit and B.R. Chaudhary, 2010. Sodium azide enduced mutagenesis in fenugreek
(Trigolella foenum graecum linn.) Indian Journals. 33 (4): 235 - 241.

Reddy, P.V. and Reddy, A.N. 1991. Genetic variability in fenugreek (Trigonella foenum-graecum L.). Indian Cocoa, Arecanut and Spices J., 15: 49-52.

Smith, A. 1982. Selected materials for turmeric, coriander seed, cumin seed, fenugreek seed and curry powder. Tropical Product Institute, London Co. 165: 7-45.

\section{How to cite this article:}

Akash T. Ingle, Amol D. Sable and Rahul K. Zote. 2018. Studies on Morphological and Phytochemical Variation between Two Varieties of Fenugreek (Trigonella foenum-graecum L.) at Different Concentration of Sodium Azide. Int.J.Curr.Microbiol.App.Sci. 7(10): 1655-1661. doi: https://doi.org/10.20546/ijcmas.2018.710.189 